\title{
A VIDA É DURA MEU IRMÃO
}

\author{
João Vitor Andrade
}

Especializando em Enfermagem em Saúde Mental e Psiquiátrica na Universidade de Saúde Paulo. Graduado em Enfermagem.

Essa é a história da vida real, que serve para exemplificação

Sobre perdas, desesperança e decepção

Criado na quebrada, entre vielas e caselas o jow era sensação

Mas por não ter tido sorte, viveu uma imposição

No momento em que estive com ele, repetia um jargão

Dizia incessantemente, a vida é dura meu irmão

Se envolveu com o crime, com drogas e com a prostituição

Nessas idas e vindas, foi pego em uma armação

Após o ocorrido, tiraram dele a esposa, a filha e a curtição

Com sangue nos olhos quis justiça, e a fez com a própria mão

No momento em que estive com ele, repetia um jargão

Dizia incessantemente, a vida é dura meu irmão

Mas na vida peça pequena, pouco importa, ainda mais se for peão

Então o jow foi pego e lançado na prisão

Lá dentro viu o mundo desabar, ficando totalmente sem chão

Hoje leva vida de detento, já há 12 anos na escuridão

No momento em que estive com ele, repetia um jargão

Dizia incessantemente, a vida é dura meu irmão

Conheci ele em um atendimento, que oportunizou gratidão 
| Revista Transgressões: ciências criminais em debate, v. 7, n. 2, dezembro de 2019

Apenas por tê-lo chamado pelo nome, sem qualquer condenação

Ele entristecido me contou toda essa situação

Lamentou profundamente e disse que busca perdão

No momento em que estive com ele, repetia um jargão

Dizia incessantemente, a vida é dura meu irmão

Pensou até em tirar a própria vida, como meio de redenção

Disse que chora diariamente por essa castigação

Então olhei em seus olhos e lhe ofertei compaixão

Pois, mesmo que seja difícil, para tudo existe renovação

No momento em que estive com ele, repetia um jargão

Dizia incessantemente, a vida é dura meu irmão

Mesmo que todos virem as costas e a sociedade toda diga não

Não podemos perder a esperança e nem deixar de acreditar em nossa Salvação

No momento em que estive com ele, até entendi o jargão

A vida é dura meu irmão, sobretudo para os desprezados em nosso Brasil nação. 